Semina $\square \quad \mathrm{Nr} 16$

Scientiarum 2017

s. $67-93$

DOI: http://dx.doi.org/10.15633/ss.2485

Radosław Siedliński

\title{
Genocentryzm versus teoria systemów rozwojowych. Dwa konkurencyjne sposoby rozumienia informacji w biologii współczesnej
}

Obserwacja rozwoju dowolnego żywego organizmu napawa nas zdumieniem: jak to możliwe, że pojedyncza komórka jajowa jest w stanie, poprzez szereg podziałów, rozwinąć się do postaci embrionu, który następnie przekształca się w kompletny, nieprawdopodobnie złożony organizm? Zdumienie to prowadzi z kolei do zadania pytania o mechanizmy tak niebywałej przemiany. Jak jest ona możliwa? Jakie czynniki ją determinują? Mamy tu do czynienia ze szczegółową postacią ogólniejszego zagadnienia: jakie jest źródło porządku w biosferze?

Na pytanie to udzielano rozmaitych odpowiedzi. Wskazywano na udział czynnika celowo działającego w świecie (William Paley), odwoływano się do ślepego mechanizmu doboru naturalnego (Karol Darwin), sugerowano działanie praw fizyki (D'Arcy Thompson), zwracano uwagę na zjawisko emergencji (Charlie Dunbar Broad). W latach pięćdziesiątych XX wieku pod wpływem inspiracji czerpanych z obszaru teorii informacji oraz cybernetyki udzielono odpowiedzi specyficznej: czynnikiem determinującym jest in for m a cja. Układy żywe tym się różnią od nieożywionych, że są kontrolowane przez informację, która podlega ciagłej modyfikacji oraz historycznej kumulacji, natomiast z pokolenia na pokolenie jest przekazywana droga 
genetyczna. W tym samym czasie opisano przestrzenną strukturę DNA (Francis Crick, James Watson), nieco później zaś ścisłą zależność między nią a strukturą łańcuchów białkowych (Heinrich Matthaei, Marshall Nirenberg). Po tych przełomowych odkryciach stopniowo upowszechniła się idea, że informacja determinująca rozwój osobniczy (ontogenezę) organizmu jest zapisana w sekwencjach nukleotydów tworzących łańcuch DNA. Tym samym informacja rozwojowa została utożsamiona z molekularną informacją genetyczna.

Sposób myślenia o świecie ożywionym zdominowany został przez model genocentryczny, który w połowie lat sześćdziesiątych XX wieku był już dobrze ukształtowaną struktura epistemologiczną ${ }^{1}$. Za jego fundamenty uznać można przypisywanie cząsteczce DNA dwóch cech, którymi są: zdolność do replikowania samej siebie oraz zdolność do budowania innych czactec z e k. Przekonanie o występowaniu obu cech, aczkolwiek powszechne, jest fałszywe ${ }^{2}$. Uzupełnione sformułowana jeszcze na początku lat sześćdziesiątych idea tzw. programu genetycznego, głosząca, iż „genom zawiera nie tylko zestaw planów budowy [organizmu], lecz również skoordynowany program syntezy białek wraz ze środkami kontrolujacymi jego wykonanie"3, konstytuują zaś paradygmat genocentryczny obowiązujący we współczesnej biologii ${ }^{4}$. W jego ramach molekularnie rozumiane geny obdarzono wyjątkową moca sprawcza, zadanie kompletnego opisania ludzkiego genomu uznano zaś za „Święty Graal” biologii ${ }^{5}$. Amerykański ewolucjonista i genetyk Richard Lewontin podsumował taką sytuację słowami: „Bio-

1 Zob. S. M. Downes, Biological Information, w: The Philosophy of Science: An Encyclopedia, ed. S. Sarkar, J. Pfeifer, New York 2004, s. 64-68.

2 Zob. R. Lewontin, It ain't Necessarily so. The Dream of the Human Genome and Other Illusions, New York 2001, s. 139-141.

3 F. Jacob, J. Monod, Genetic Regulatory Mechanisms in the Synthesis of Proteins, „Journal of Molecular Biology” 3 (1961) iss. 3, s. 354 (jeśli nie zaznaczono inaczej, tłum. własne).

4 Zob. P. Łuków, C. Żekanowski, Pojęcie genu i genocentryczny paradygmat biologii, „Przegląd Filozoficzny” 14 (2005) nr 53, s. 85-105.

5 Zob. W. Gilbert, A Vision of the Grail, w: The Code of Codes. Scientific and Social Issues in the Human Genome Project, ed. D. J. Kevles, L. Hood, Cambridge 1992, s. 83-97. 
logia molekularna jest dziś religia, a biologowie molekularni są jej prorokami" .

W centrum współczesnej biologii znajduje się zatem pojęcie informacji, bez którego trudno wyobrazić sobie dziś uprawianie wielu kluczowych dyscyplin biologicznych. Przy jego pomocy można scharakteryzować zarówno rozmaite typy procesów biologicznych, jak i dyscypliny je badajace ${ }^{7}$. Z tej perspektywy np. biologia molekularna zajmuje się badaniem sposobu, w jaki informacja zapisana w DNA wykorzystywana jest do budowania białek; biologia rozwoju bada, jak informacja genetyczna kształtuje fenotyp od postaci zygoty aż do dorosłego osobnika; biologia e w ol u c y j n a stara się odpowiedzieć na pytanie, w jaki sposób informacja genetyczna w ogóle została zapisana w DNA w takiej, a nie innej postaci oraz jak zmienia się ona w czasie. Również sedno badań nad bi o g e n e z ą można wyrazić w postaci pytania o pochodzenie informacji genetycznej ${ }^{8}$. Jednak pomimo powszechnego w biologii operowania pojęciem informacji, ustalenie, co dokładnie się pod nim kryje, nastręcza wielu kłopotów i jest wciąż przedmiotem debat.

Wydaje się, że najmniej kontrowersyjnym i najlepiej poznanym mechanizmem informacyjnym obecnym w świecie ożywionym jest funkcjonowanie tzw. kodu genetycznego ${ }^{9}$. Mianem tym opatrzono stała zależność między kolejnością nukleotydów w łańcuchu DNA a kolejnością aminokwasów w łańcuchu białkowym. Dokładniej rzecz ujmując: łańcuch DNA zbudowany jest z czterech typów nukleotydów (A, C, G, T), których kolejne trójki (tzw. tryplety lub kodony) odpowiadają poszczególnym aminokwasom będącym komponentami łańcucha polipeptydowego, tworzącego białko. Istnieje jednoznaczne przyporządkowanie między liniowa

\footnotetext{
6 R. Lewontin, It ain't Necessarily so..., dz. cyt., s. 137.

7 Zob. E. Szathmáry, J. Maynard Smith, The Major Evolutionary Transitions, „Nature” 374 (1995), s. 227-232.

8 Zob. B. O. Küppers, Geneza informacji biologicznej. Filozoficzne problemy powstania życia, tłum. W. Ługowski, Warszawa 1991.

9 Zob. P. Godfrey-Smith, K. Sterelny, Biological Information, w: The Stanford Encyclopedia of Philosophy (Summer 2016 Edition), ed. E. N. Zalta, https://plato. stanford.edu/entries/information-biological (22.11.2017).
} 
sekwencją trypletów a liniową sekwencją aminokwasów w łańcuchu białkowym:

\section{TCA|GAG|GTG|AAA|TGC|TAT|GGT 1 I 11 11
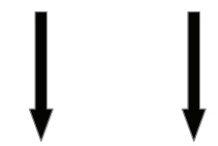 \\ Ser Glu
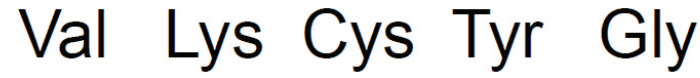

Właśnie ze względu na ów fakt struktura DNA traktowana jest jako nośnik informacji o tzw. pierwszorzędowej strukturze białek. Zanim jednak informacja zakodowana w DNA zostanie przełożona na białka, muszą zajść inne procesy. Informacja ta jest najpierw przepisywana (w procesie transkrypcji) z DNA na inny kwas nukleinowy - RNA, a następnie tłumaczona (w procesie translacji) z RNA na białko ${ }^{10}$.

Szczegóły całego mechanizmu są dobrze poznane, a używanie do jego opisu terminologii informacyjnej nie budzi kontrowersji. Niemniej jednak informacyjna (również w znaczeniu - „formujacca”, „przyczynująca”) interpretacja roli pełnionej przez DNA w komórce rozciaga się daleko poza kodowanie struktury pierwszorzędowej. Białka, będące podstawowymi składnikami strukturalnymi i funkcjonalnymi komórek, zaangażowane są bowiem w konstrukcję kompletnego fenotypu. Otrzymujemy zatem następujacy schemat:

$$
\mathrm{DNA} \rightarrow \mathrm{RNA} \rightarrow \text { białka } \rightarrow \text { fenotyp }
$$

10 Operowanie terminologią opartą na pojęciu informacji oraz szeregu pojęć z nią sprzężonych (,kod”, „program”, „translacja”, „transkrypcja” etc.) jest charakterystyczne dla genocentryzmu (zob. P. Łuków, C. Żekanowski, Pojęcie genu..., dz. cyt.). Wplecenie tego rodzaju terminów w siatkę pojęciową nowoczesnej biologii molekularnej jest efektem inspiracji czerpanych przez jej pionierów (M. Delbrücka, J. Lederberga, F. Cricka, J. Watsona i in.) bezpośrednio z matematycznej teorii informacji, cybernetyki oraz informatyki (zob. M. Cobb, Największa tajemnica życia. Jak rozszyfrowano kod genetyczny, tłum. A. Tuz, Warszawa 2017). 
w którym strzałki przedstawiają zachodzenie relacji przyczynowania czy też determinowania kolejnych etapów. Tym samym DNA urasta do rangi causa prima żywego organizmu ${ }^{11}$. W taki oto skrajnie uproszczony sposób rola DNA postrzegana jest często zarówno przez naukowców, jak i przez laików zainteresowanych nauką ${ }^{12}$.

Kłopot polega jednak na tym, że redukowanie komórki do zestawu białek jest uproszczeniem. Do jej prawidłowego funkcjonowania niezbędnych jest wiele innych związków chemicznych (kwasów tłuszczowych, cukrów, jonów), które nie są kodowane przez DNA. I dopiero niezwykle złożona sieć łacczacych je relacji chemicznych (ostatnia strzałka na powyższym schemacie) tworzy kompletny fenotyp komórkowy. Ciężko wobec tego uznać go za bezpośredni efekt odczytu informacji genetycznej ${ }^{13}$. Żywy organizm to złożony system współzależnych reakcji chemicznych, którego stabilność i funkcjonalność zależą od wielu rozmaitych czynników wewnętrznych i zewnętrznych ('srodowiskowych).

Szczególnie często informacja genetyczna przywoływana bywa w dwóch przypadkach: w celu wyjaśnienia procesów rozwojowych (informacja genetyczna = informacja rozwojowa) oraz jako czynnik wyjaśniający międzypokoleniowe przekazywanie cech, czyli zjawisko dziedziczności (informacja genetyczna = informacja dziedziczna). W niniejszym artykule odwoływać się będę przede wszystkim do pierwszego, rozwojowego rozumienia pojęcia informacji. W jego dalszej części przedstawię funkcjonujące w literaturze przedmiotu dwa różne rozumienia pojęcia informacji biologicznej (bioinformacji). Najpierw krótko omówię inspirowane matematyczną teorią informacji stosunkowo proste ujęcie kauzalne. Następnie przedstawię bogatsze od niego ujęcie intencjonalne (semantyczne) autorstwa Johna Maynarda Smitha, wydające się lepszym kandydatem dla peł-

11 Przytoczyć tu można komentarz filozofa biologii Davida Hulla, który stwierdził, że za wyjątkiem transmisji kulturowej u niektórych gatunków zwierząt geny sa jedyną przyczyną istnienia uporządkowanych struktur w świecie istot żywych. Zob. K. Sterelny, K. C. Smith, M. Dickson, The Extended Replicator, „Biology and Philosophy” 11 (1996), s. 380.

12 Zob. E. F. Keller, The Century of the Gene, Cambridge 2000.

13 Zob. D. Noble, The Music of Life. Biology Beyond Genes, Oxford 2006. 
niejszego oddania specyfiki bioinformacji. W dalszej kolejności zaprezentuję wybrane zarzuty stawiane genocentrycznemu podejściu Maynarda Smitha przez krytyków oraz przedstawię konkurencyjne ujęcie intencjonalności autorstwa Evy Jablonki. Następnie przejdę do prezentacji tzw. teorii systemów rozwojowych, operujaccej diametralnie odmiennym rozumieniem pojęcia bioinformacji i pozostającej w wyraźnej opozycji wobec genocentryzmu.

\section{Kauzalne rozumienie informacji - informacja jako korelacja - parity thesis}

W ujęciu tym informacja jest cokolwiek, co zmienia stan fizyczny układu. Dokładniej rzecz ujmując: informacja jest tu pewną mierzalną własnością sygnału przesyłanego przez kanał łączący dwa układy fizyczne, z których jeden jest nadawca, a drugi - odbiorca. Informacja jest więc k or el a cj ą między stanami, w których znajdują się dwa układy fizyczne. Odbiornik uznać można za nośnik informacji o źródle, jeżeli jego stany są systematycznie skorelowane ze stanami źródła. Odbiornik dostarcza więcej informacji o źródle, jeżeli jego obserwacja pozwala na bardziej dokładny opis jego stanu fizycznego, mniej - jeżeli pozwala na opis mniej dokładny. W tym sensie dym niesie informację o ogniu, fenotyp zaś niesie informację o genotypie ${ }^{14}$. Posługiwanie się tego typu rozumieniem informacji nie wprowadza żadnego specjalnego rodzaju relacji lub własności. Zakłada się przy tym, że obserwowane korelacje zakotwiczone sa w faktycznych relacjach przyczynowych, ufundowanych na znanych nauce (bądź możliwych do poznania) prawach przyrody.

Ujęcie to okazuje się jednak niewystarczające dla tych badaczy, którzy chcą uchwycić specyfikę informacji zapisanej w DNA. Chcąc przy jego pomocy opisać relację między genotypem a fenotypem, możemy rzecz jasna potraktować geny jako źródło informacji, środowisko jako kanał przesyłu, fenotyp zaś jako jej odbiorcę. Jest to możliwe, zważywszy na fakt istnienia wyraźnej korelacji między

14 Zob. P. Griffiths, Genetic Information: A Metaphor in Search of a Theory, „Philosophy of Science" 68 (2001), s. 394-412. 
pewnymi fragmentami DNA kodujaccymi białka (genami) a pewnymi cechami fenotypowymi. Nic jednak nie powstrzymuje nas przed odwróceniem sytuacji i stwierdzeniem, że korelacja zachodzi między elementami środowiska a fenotypem. Wówczas geny traktować możemy jako kanał przekazywania informacji, a nie jako jej źródło. $\mathrm{Na}$ gruncie kauzalnej teorii informacji zabieg taki jest jak najbardziej możliwy i nie budzi kontrowersji. Krótko mówiąc: czynniki środowiskowe również mogą być traktowane jako źródło informacji o fenotypie. Konsekwencje takiego stanu rzeczy sa treścią zasady opatrywanej w filozofii biologii mianem parity thesis, głoszacej, że uprzywilejowywanie jednych typów przyczyn kosztem innych jest nadużyciem mogacym prowadzić do błędnych wniosków ${ }^{15}$. Tym samym twierdzenie, iż wyłącznie geny traktować można jako źródło informacji biologicznej, na gruncie ujęcia kauzalnego byłoby trudne do obronienia. Wydaje się zatem, że kauzalne rozumienie informacji jako korelacji między stanami układów fizycznych jest zbyt słabe, aby oddać specyfikę informacji genetycznej.

\section{Intencjonalne rozumienie informacji - ujęcie Johna Maynarda Smitha}

Chcąc opisać zależność między genami a białkami tudzież cechami fenotypowymi, potrzebujemy pojęcia informacji zdolnego oddać fakt, że poszczególne układy i organy istnieją w istotach żywych po coś, że mają konkretne zadanie do spełnienia ${ }^{16}$. Część badaczy skłoniło to do poszukiwania bogatszego ujęcia bioinformacji. Jedną z częściej dyskutowanych w najnowszej literaturze propozycji jest koncepcja przedstawiona przez wybitnego brytyjskiego ewolucjonistę

15 Zob. P. Griffiths, R. Knight, What Is the Developmentalist Challenge?, „Philosophy of Science" 65 (1998) no. 2, s. 253-258.

16 Klasycznym przykładem pokazującym słabość ujęcia kauzalnego jest serce, które pompując krew, równocześnie wydaje dźwięki. Między skurczami mięśnia sercowego a krążeniem krwi w żyłach oraz słyszeniem przez nas dźwięku bicia istnieje ewidentna relacja przyczynowa. Niemniej funkcją serca nie jest wydawanie dźwięku, lecz wyłącznie pompowanie krwi. Zob. L. Wright, Functions, „The Philosophical Review" 82 (1973) no. 2, s. 139-168. 
Johna Maynarda Smitha. Fundamentalne jego zdaniem rozróżnienie w biologii zachodzi między przyczynami genetycznymi a środowiskowymi. Tylko cechy determinowane genetycznie mogą być dziedziczone, a te zależne od środowiska wprost przeciwnie. Tym samym podstawowy mechanizm ewolucji - dobór naturalny - może operować wyłącznie na dziedzicznym materiale genetycznym. Ten zaś decyduje o poziomie dostosowania organizmu będącego jego nosicielem do środowiska. Do wyrażenia tej zależności potrzebne jest odpowiednio bogate pojęcie informacji ${ }^{17}$.

W biologii stwierdzenie, że A niesie informację o $\mathrm{B}$, pociaga za sobą stwierdzenie, że A posiada taka, a nie inną postać dlatego, że niesie tę informację. Cząsteczka DNA ma konkretną sekwencję [nukleotydów] dlatego, że wyznacza konkretne białko; chmura nie jest ciemna dlatego, że zwiastuje deszcz. Źródłem owej intencjonalności jest dobór naturalny ${ }^{18}$.

Ażeby uchwycić specyfikę świata ożywionego, potrzebujemy zatem rozumienia informacji zdolnego wyrazić celowość. Kodująca sekwencja nukleotydów w DNA ma zaś bardzo konkretny cel: konstrukcję odpowiedniego białka. Możemy zatem uznać gen za nośnik informacji ze względu na cel, rozumiany tu jako funkcja pełniona w organizmie przez zakodowane w nim białko. Krótko mówiąc: gen zawiera informację nie przez wzgląd na korelację z cechą fenotypowa, lecz przede wszystkim dlatego, że jego funkcją jest wytworzenie tejże konkretnej cechy (poprzez konstrukcję białka w nim zakodowanego). Geny sa intencjonalnie nakierowane na efekt: koduja konkretną cechę, a ich funkcją jest powodowanie pojawienia się tejże cechy ${ }^{19}$. Ostatecznym celem całości informacji zakodowanej w genomie jest zbudowanie kompletnego i zdolnego do życia organizmu. Za tak rozumianą intencjonalnością nie stoi oczywiście jakikolwiek celowo działający agent, lecz ślepy proces ewolucji w drodze doboru

17 Zob. J. Maynard Smith, The Concept of Information in Biology, „Philosophy of Science" 67 (2000) no. 2, s. 177-194.

18 J. Maynard Smith, The Concept of Information..., dz. cyt., s. 189-190.

19 Zob. P. Łuków, C. Żekanowski, Pojęcie genu..., dz. cyt., s. 94. 
naturalnego faworyzujący osobniki o wyższym poziomie dostosowania. Można zatem rzec, iż DNA zawiera zakodowane instrukcje, jak wytworzyć cechy fenotypowe, które były faworyzowane przez dobór w procesie ewolucji. Propozycja Maynarda Smitha jest zatem wyraźnie genocentryczna: nośnikami intencjonalnie rozumianej informacji są w niej wyłącznie molekularnie traktowane geny.

Uzasadniając konieczność przyjęcia mocniejszego niż tylko kauzalne rozumienia informacji biologicznej, Maynard Smith wskazuje na dwie specyficzne własności kodu genetycznego: jego arbitralność oraz podatność na błędy. A r bitralno ść kodu genetycznego zasadza się na fakcie, że nie widać żadnej chemicznej konieczności, aby tryplety nukleotydowe kodowały aminokwasy akurat w ten sposób, który faktycznie obserwujemy w naturze. Kod genetyczny mógłby być inny. W tym sensie można mówić, że ma on charakter symbolicz$n y^{20}$. Relacja między genem a cechą fenotypową z nim skorelowana nabiera w tym ujęciu charakteru podobnego do relacji łączącej słowo z obiektem nim opisywanym. Druga własność kodu - p o d a t n o ść na błędy w odczycie (misreading) - wydaje się równie ciekawa. Jeżeli przyjmiemy, że gen nie jest wyłącznie skorelowany z cechą fenotypowa, lecz zawiera zakodowaną informację niezbędną do jej zaistnienia, to brak danej cechy w fenotypie (lub pojawienie się cechy nietypowej) traktować można jako efekt błędnego odczytania informacji genetycznej. Co więcej, okazuje się, że komórki zawierają wyspecjalizowaną maszynerię białkowa, istniejącą właśnie po to, aby znajdować i korygować takie błędy ${ }^{21}$. Łatwo zauważyć, że w przypadku informacji rozumianej wyłacznie jako korelacja taka sytuacja nie zachodzi. Trudno byłoby powiedzieć, że dym jest błędnie skorelowany z ogniem, a kolor chmury burzowej - z jej nasyceniem cząsteczkami wody. Obie wymienione cechy łaczą naturalny kod genetyczny z kodami sztucznymi, zaprojektowanymi przez człowieka, takimi jak kod Morse'a lub kod ASCII'22.

20 Zob. J. Maynard Smith, The Concept of Information..., dz. cyt., s. 185.

21 Zob. P. Godfrey-Smith, Information, Arbitrariness, and Selection: Comments on Maynard Smith, „Philosophy of Science” 67 (2000) no. 2, s. 202-207.

22 Zob. J. Maynard Smith, The Concept of Information..., dz. cyt., s. 183. 


\section{Krytyka teorii Maynarda Smitha}

Zaproponowane przez Maynarda Smitha intencjonalne rozumienie bioinformacji, aczkolwiek interesujace, poddane zostało wielorakiej krytyce. Filozof biologii Peter Godfrey-Smith zauważa, że orzekanie arbitralności kodu genetycznego jest problematyczne. W istocie bowiem każdą relację kauzalną można postrzegać jako arbitralna, o ile tylko między pierwszą przyczyną a efektem finalnym pośredniczy odpowiednio długi łańcuch przyczyn pośrednich, z których każda może zostać zakłócona, co wpłynie na efekt final$n^{23}$. Z kolei Kim Sterelny zwraca uwagę, że nośnikami informacji w rozumieniu Maynarda Smitha mogą być nie tylko geny, ale i inne elementy wewnątrzkomórkowe. Gradienty chemiczne w cytoplazmie komórki jajowej decyduja o włączaniu poszczególnych genów we wczesnej fazie rozwoju embrionalnego. Taka jest ich funkcja. Czy powinniśmy zatem powiedzieć, że gradienty, tak jak geny, są nośnikami bioinformacji? ${ }^{24}$ Co więcej, wiele gatunków zwierząt i roślin dziedziczy symbiotyczne drobnoustroje, które przekazywane są wewnątrz komórki jajowej i spełniają istotne funkcje w prawidłowym rozwoju embrionu gospodarza ${ }^{25}$. Mechanizmy takiego przekazu zostały najwyraźniej wyselekcjonowane przez dobór naturalny. Czy wobec tego symbionty również należy potraktować jako nośniki informacji intencjonalnej?26 Sterelny zadaje również inne ważne pytanie: czy możemy założyć istnienie dyskretnego, względnie autonomicz-

23 Zob. P. Godfrey-Smith, Information in Biology, w: The Cambridge Companion to the Philosophy of Biology, ed. D. L. Hull, M. Ruse, Cambridge 2007, s. 103119. Okazuje się jednak, że istnieją przesłanki, aby domniemywać, iż kod genetyczny przyją znaną nam postać nie na skutek czystego przypadku, lecz celem minimalizowania skutków losowych pomyłek w odczycie informacji zapisanej w DNA. Zob. S. Freeland, L. Hurst, Ewolucja języka genów, „Świat Nauki” (2004) nr 5, s. 56-63.

${ }_{24}$ Zob. K. Sterelny, Symbiosis, Evolvability and Modularity, w: Modularity in Development and Evolution, ed. G. Schlösser, G. P. Wagner, Chicago 2004, s. 490-518.

25 Zob. S. A. Frank, Host Control of Symbiont Transmission: The Separation of Symbionts into Germ and Soma, „The American Naturalist” 148 (1996) no. 6, s. $1113-1124$.

26 Zob. K. Sterelny, The "Genetic Program" Program: A Commentary on Maynard Smith on Information in Biology, „Philosophy of Science” 67 (2000) no. 2, s. 195-201. 
nego mechanizmu mapującego z przestrzeni genotypu w przestrzeń fenotypu? Choć jesteśmy w stanie wskazać mechanizm mapowania różnic genotypowych na różnice białkowe (odkryto go w latach pięćdziesiątych i sześćdziesiątych XX wieku), nie oznacza to, że analogiczny mechanizm musi istnieć dla nadrzędnego poziomu organizacji, jakim jest kompletny fenotyp. Załóżmy, że geny są nośnikami informacji intencjonalnej w sensie Maynarda Smitha. Wiemy, że istnieje wyraźna i stabilna odpowiedniość między sekwencjami DNA a cechami fenotypowymi. Wiemy też, że pierwszy poziom tej odpowiedniości - kod łączący geny z białkami - ma charakter dyskretny. Nie wiemy jednak, czy ewentualne kolejne poziomy mają taki sam charakter. Czy np. drobne różnice stężeń związków chemicznych w cytoplazmie komórkowej nie mogłyby być odczytywane przez jakiś analogowy odpowiednik i przekładać się na drobne różnice fenotypowe?27 Zważywszy na fakt, że zakres zmienności warunkowanej czynnikami epigenetycznymi jest wciąż obiektem badań, pytanie to pozostaje otwarte.

Ciekawą krytykę wycelowaną w analogię między ekspresją materiału genetycznego a wykonaniem programu komputerowego sformułował Ma r c el W e b e r ${ }^{28}$. Otóż Maynard Smith wprost przyrównuje ewolucyjne kształtowanie informacji zapisanej $\mathrm{w}$ genomie do pisania programu przez programistę. Zarówno genom, jak i program pisany przez człowieka są nośnikami informacji intencjonalnej ${ }^{29}$. Jeżeli tak, powiada Weber, to odpowiednio przygotowany inżynier, mając wgląd w kod źródłowy programu, byłby w stanie wywnioskować zeń zamysł programisty. Przy bliższej inspekcji analogii Maynarda Smitha z tego punktu widzenia wyłaniają się następujące dwa problemy. Primo: DNA może zawierać kodujace fragmenty powstałe w wyniku czysto losowych mutacji i majace korzystny wpływ na zdolność przeżycia swojego nosiciela. Fragmentom takim winniśmy przypisać informację intencjonalną dokładnie tak samo jak genom, które zostały uprzednio wyselekcjonowane przez dobór naturalny.

27 Zob. K. Sterelny, The “Genetic Program” Program..., dz. cyt.

28 Zob. M. Weber, Philosophy of Experimental Biology, Cambridge 2005.

29 Zob. J. Maynard Smith, The Concept of Information..., dz. cyt., s. 190. 
Skoro bowiem ich funkcja jest taka sama jak genów „dostrzeżonych” przez dobór, to nie widać powodów, dla których nie mielibyśmy tak uczynić. Niemniej jednak w semantycznym ujęciu Maynarda Smitha nie da się im przypisać posiadania takowej informacji, jako że ta ugruntowana jest właśnie w działaniu doboru naturalnego ${ }^{30}$.

Secundo: zapytajmy, co dokładnie ów odpowiednio przygotowany inżynier byłby w stanie wywnioskować z analizy kodu źródłowego programu. Maynard Smith sugeruje, że program wciela (embody) intencje programisty, a zatem jego stany mentalne. Kłopot polega jednak na tym, że stany mentalne, o które tutaj chodzi, posiadaja wyłącznie ludzie. Program komputerowy jest sekwencją symboli, która nabiera znaczenia jedynie dla programistów, rozumiejących, co dany program robi i w jakim celu. Co więcej, daną maszynę liczącą uznać możemy za komputer wyłącznie w odniesieniu do celowo działającego agenta w odpowiedni sposób interpretującego stany fizyczne urządzenia. Natomiast celowo działający i posiadający stany mentalne programista jest dokładnie tym, czego brakuje w świecie przyrody. Przypisanie posiadania stanów mentalnych, a co za tym idzie - intencji mechanizmowi doboru naturalnego wymagałoby nielichej ekwilibrystyki intelektualnej. Dlatego jest on kiepskim kandydatem do bycia instancją nadajacca znaczenie w ramach świata ożywionego ${ }^{31}$.

Z jeszcze innych pozycji wyszła krytyka propozycji Maynarda Smitha przedstawiona przez izraelska biolog polskiego pochodzenia Evę J a blonkę. Brytyjski ewolucjonista, o czym pisałem powyżej, przyjmuje, iż intencjonalność informacji genetycznej wynika z faktu jej wyselekcjonowania w procesie ewolucji darwinowskiej. Informacja genetyczna została niejako zaprogramowana przez dobór naturalny, aby pełnić określone funkcje ${ }^{32}$. Ujmujac rzecz w kategoriach teorii informacji, możemy zatem powiedzieć, że źródło jej intencjonalności znajduje się po stronie nadawcy komunikatu. Jablonka natomiast odwraca tę sytuację, przyjmując, że intencjonal-

30 Zob. M. Weber, Philosophy of Experimental..., dz. cyt., s. 252.

31 Zob. M. Weber, Philosophy of Experimental..., dz. cyt., s. 252.

32 Zob. J. Maynard Smith, The Concept of Information..., dz. cyt., s. 190. 
ność informacji zasadza się na możności jej wykorzystania na rzecz interesów odbior cy.

O źródle - obiekcie bądź procesie - można powiedzieć, że posiada informację, jeżeli odbiorca reaguje na nie w odpowiedni sposób. Reakcja odbiorcy na źródło musi dopuszczać możność zmiany stanu odbiorcy na sposób dlań (zazwyczaj) korzystny. Ponadto istnieć musi spójna relacja między zmianami stanu źródła a odpowiadającymi im zmianami stanu odbiorcy ${ }^{33}$.

W świetle podanej definicji geny przestają pełnić wyróżnioną rolę informacyjna, stając się zaledwie jednym z wielu możliwych źródeł bioinformacji. Zasadnicza różnica między propozycją Maynarda Smitha a koncepcja Jablonki tkwi zatem w tym, że w tej drugiej nośnikami informacji moga być obiekty bądź procesy, które nie zostały „zaprogramowane” przez dobór do pełnienia jakichkolwiek funkcji. Stąd przekonanie Jablonki, że zarówno natężenie oświetlenia, kolor chmur, stężenie związku chemicznego, jak też określony fragment DNA lub RNA moga, w pewnych warunkach i dla określonych odbiorców, stać się źródłami informacji ${ }^{34}$. O danym obiekcie możemy zatem powiedzieć, że jest nośnikiem informacji, nie dlatego że został wyselekcjonowany przez dobór, lecz ponieważ reakcja odbiorcy na ów bodziec została wyselekcjonowana ${ }^{35}$.

\section{Krytyka genocentryzmu}

Teoria informacji Maynarda Smitha może zostać uznana za modelowy przykład genocentryzmu, będącego w biologii współczesnej zjawiskiem powszechnym. Nie oznacza to jednak, że ograniczanie zakresu bioinformacji do kwasów nukleinowych nie budzi żadnych kontrowersji. Wielu spośród przywoływanych krytyków propozycji Maynarda Smi-

${ }_{33}$ E. Jablonka, Information: Its Interpretation, Its Inheritance, and Its Sharing, „Philosophy of Science” 69 (2002) no. 4, s. 582.

${ }_{34}$ Zob. E. Jablonka, Information: Its Interpretation..., dz. cyt., s. 583.

35 Zob. K. Waters, Molecular Genetics, w: The Stanford Encyclopedia of Philosophy, ed. E. N. Zalta, https://plato.stanford.edu/entries/molecular-genetics (22.11.2017). 
tha odsłania uproszczenia i ukryte założenia u podstaw paradygmatu genocentrycznego. Godfrey-Smith wskazuje, że odwołanie się do kodu genetycznego rozwiąuje wyłącznie jeden problem: kwestię liniowego uszeregowania aminokwasów w łańcuchu białkowym. Poza tym kontekstem mówienie o kodowaniu czegokolwiek, w szczególności cech fenotypowych, przez geny jest nieuprawnione ${ }^{36}$. Z kolei Jablonka uważa za niepokojący fakt, że dyskusja o informacji biologicznej domyślnie przyjmuje DNA i system transkrypcyjno-translacyjny za modelowy przykład układu informacyjnego. Tym samym już w punkcie wyjścia stawia się geny na uprzywilejowanej pozycji, niejako sugerując wtórność bądź niepełność innych systemów przekazywania informacji ${ }^{37}$.

$\mathrm{Z}$ ciekawą krytyką genocentryzmu wystapił biolog Frederik $\mathrm{Nijh}$ o u t, identyfikujac trzy fundamentalne przekonania dotyczace relacji między genami a ontogenezą organizmów: 1) geny kontroluja procesy rozwojowe, 2) geny są nośnikami informacji, 3) genom zawiera program dla rozwoju organizmu ${ }^{38}$. Żadnego z nich nie da się utrzymać. Po pierwsze: geny nie moga kontrolować procesów rozwojowych, gdyż cząsteczki DNA są całkowicie bierne chemicznie i niczego nie „robią”. Moga co najwyżej zostać uznane za repozytorium wzorów dla pierwszorzędowej struktury białek, aczkolwiek aby można było z nich skorzystać, wymagane jest uprzednie istnienie wyspecjalizowanej maszynerii białkowej, która na nich operuje ${ }^{39}$. I nawet istnienie systemu genów regulatorowych niczego tutaj zasadniczo nie zmienia, jako że z jednej strony geny te również podlegają regulacji przez chemiczne czynniki wewnątrzkomórkowe, natomiast z drugiej oddziałują nie bezpośrednio, lecz poprzez swoje produkty, czyli białka ${ }^{40}$.

Po drugie: nie dysponujemy powszechnie akceptowaną i niekontrowersyjną definicją informacji w ogóle, a bioinformacji w szczególności. Nie istnieje również, przynajmniej na razie, żadna metoda

36 Zob. P. Godfrey-Smith, On the Theoretical Role of “Genetic Coding”, „Philosophy of Science" 67 (2000), s. 26-44.

37 Zob. E. Jablonka, Information: Its Interpretation..., dz. cyt., s. 579.

38 Zob. F. Nijhout, Metaphors and the Role of Genes in Development, „BioEssays” 12 (1990) iss. 9, s. 441-446.

${ }_{39}$ Zob. R. Lewontin, It ain't Necessarily so..., dz. cyt., s. 141-142.

40 Zob. F. Nijhout, Metaphors and the Role..., dz. cyt., s. 442. 
mierzenia ilości informacji w systemie ożywionym. W istocie zatem kiedy mówimy, że geny niosą informację, chodzi nam wyłącznie o fakt, że struktura fragmentu DNA jest wzorem dla struktury łańcucha polipeptydowego, który (po zwinięciu do odpowiedniej postaci trójwymiarowej) stanie się białkiem. Wszelkie użycia tego terminu poza powyższym kontekstem sa jedynie wyrazem naszych przekonań czy też oczekiwań, że genom „w jakiś sposób” zawiera informacje również dla bardziej złożonych własności istot żywych ${ }^{41}$.

Wreszcie po trzecie: nie ma dobrych empirycznych przesłanek na rzecz istnienia „genetycznego programu kontrolnego” dla ontogenezy. Istnieją natomiast dwa powody, dla których postulujemy jego istnienie. Primo: gdybyśmy byli w stanie zaprojektować system o poziomie złożoności choćby zbliżonym do żywej komórki, to z pewnościa jego funkcjonowanie poddalibyśmy kontroli stosownego oprogramowania. Secundo: trudno jest nam pogodzić się z myśla, że system tak złożony jak komórka mógłby być w dużym stopniu samoorganizujący się. Nie mamy bowiem dobrej teorii opisującej procesy replikacji i dziedziczenia dla takich systemów ${ }^{42}$.

Z kolei amerykańska psycholog i filozof Su sa n Oy a ma stwierdza, iż genocentryzm jest w gruncie rzeczy nowoczesną postacią starej idei preformacjonistycznej. Klasyczny preformacjonizm zakładał, że zapłodniona komórka jajowa zawiera w sobie maleńką wersję dojrzałego organizmu - homunkulusa, o którym po raz pierwszy pisał Paracelsus w XVI wieku. W tym ujęciu rozwój organizmu polega po prostu na wzroście czegoś, co zostało już uprzednio uformowane ${ }^{43}$. Genocentryczna postać preformacjonizmu jest oczywiście bardziej wyszukana. Nie ma w niej mowy o preformowanym organizmie. Jego miejsce zajmuje natomiast informacja, która zawiera plan budowy organizmu oraz program kierujący jego realizacja. Mamy tu zatem do czynienia z preformacją nie samego organizmu, ale jego zakodowanej, molekularnej reprezentacji ${ }^{44}$.

41 Zob. F. Nijhout, Metaphors and the Role..., dz. cyt., s. 443.

42 Zob. F. Nijhout, Metaphors and the Role..., dz. cyt., s. 443.

${ }_{43}$ Zob. C. Pinto-Correia, The Ovary of Eve. Egg and Sperm and Preformation, Chicago 1997.

44 Zob. S. Oyama, The Ontogeny of Information, Cambridge 1985. 
Krytyka genocentryzmu nie jest sprawą nowa. Ważną rolę w dostrzeżeniu rozmaitych słabości tego stanowiska odegrała, jak sadzę, publikacja sławnej książki brytyjskiego biologa Richarda Dawkinsa pt. Samolubny gen w roku 1976. Zarówno ona, jak i kolejna pozycja tego samego badacza - Fenotyp rozszerzony (1982) - zaowocowały szeregiem tekstów krytycznych pod adresem lansowanego w nich genocentryzmu oraz adaptacjonizmu (poglądu zakładajacego, że wszystkie cechy fenotypowe organizmów są przystosowaniami do warunków środowiskowych, powstałymi w drodze doboru naturalnego). Dawkins znalazł nieustępliwego adwersarza w osobie amerykańskiego ewolucjonisty Stephena Jaya Goulda, stąd spór między nimi toczył się długo i był niezwykle zacięty ${ }^{45}$. Innym ważnym przeciwnikiem genocentryzmu jest przywoływany już Lewontin. Na początku lat osiemdziesiątych XX wieku zakwestionował on m.in. prawomocność ostrego wyodrębniania organizmu ze środowiska, sugerując, że środowisko nie jest tłem, na którym działaja żyjące w nim organizmy, lecz raczej winno być postrzegane jako funkcja siebie samego oraz tychże organi$\mathrm{zmów}^{46}$. Sugerował również, że warunkiem pełnego zrozumienia procesów ontogenezy jest wyjście poza genocentryzm w kierunku ujęcia systemowego, uwzględniającego istnienie skomplikowanej i niejednoznacznej siatki zależności między genami, organizmem a środowiskiem ${ }^{47}$.

\section{Teoria systemów rozwojowych (DST)}

Idee rozwijane przez Lewontina zostały po raz pierwszy zaprezentowane w postaci całościowej i spójnej propozycji teoretycznej w połowie lat osiemdziesiątych, w przywołanej już książce autorstwa

${ }^{45}$ Więcej na temat tej polemiki pisze R. Gaczoł w artykule pt. Spór Richarda Dawkinsa ze Stephenem Jayem Gouldem wokót teorii samolubnego genu, „Przegląd Filozoficzno-Literacki” 31 (2011) nr 2-3, s. 87-106.

${ }^{46}$ Zob. R. Lewontin, Organism and Environment, w: Learning, Development, and Culture, ed. H. C. Plotkin, New York 1982, s. 151-170.

47 Zob. R. Lewontin, Gene, Organism and Environment, w: Evolution from Molecules to Men, ed. D. S. Bendall, Cambridge 1983, s. 273-286. 
Oyamy ${ }^{48}$. Praca ta uznawana jest dzisiaj za tekst założycielski dla nakreślonej z rozmachem ogólnej teoretycznej perspektywy dla ujmowania procesów rozwoju, dziedziczności i ewolucji ${ }^{49}$. Perspektywę tę przyjęło się opatrywać w literaturze mianem „teorii systemów rozwojowych" (Developmental Systems Theory, DST). Zwolennicy tego podejścia rozpoznają obecnie panujący w biologii paradygmat jako jednoznacznie genocentryczny. DNA traktowany jest w nim jako „czasteczka zarządzająca” (master molecule), a procesy rozwoju, dziedziczenia i ewolucji opisywane sa jako efekty zmian w jej w strukturze oraz jej międzypokoleniowego przekazywania. Rozmaite niegenetyczne przyczyny zmian zachodzacych w żywych organizmach zbierane sa pod wspólną nazwą „wpływów środowiskowych" i traktowane jako drugoplanowe. Za szczególnie wpływowa postać genocentryzmu teoretycy DST uznają koncepcję „,samolubnych genów" autorstwa Dawkinsa. DST jest pomyślana jako kontrpropozycja wobec takiego podejścia ${ }^{50}$.

Istotny z punku widzenia niniejszego artykułu trop podsuwa już sam tytuł książki Oyamy (pol. Ontogeneza informacji). Ażeby jednak właściwie go zrozumieć, należy najpierw zaprezentować zarys głównych myśli w niej przedstawionych. Podstawowym pojęciem DST jest oczywiście s y s te m rozw ojow y. Pod pojęciem tym kryje się „heterogeniczne i skomplikowane kauzalnie zbiorowisko oddziałujących między sobą obiektów oraz wpływów, które wytwarza cykl ży cia (life cycle) organizmu" "51. Elementy składajace się na owo zbiorowisko-zasoby rozwojowe (developmental resources) - mogą należeć do każdego poziomu organizacji układu ożywionego, począwszy od molekularnego, przez komórkowy, tkankowy, organizmalny, aż po ekologiczny, społeczny i - w przypadku ludzi - kulturowy. Wspólnie

48 Zob. S. Oyama, The Ontogeny of Information, dz. cyt. Przedmowę do nowego wydania książki napisał właśnie Lewontin.

${ }^{49}$ Zob. S. Oyama, P. E. Griffiths, R. D. Gray, Introduction. What Is Developmental Systems Theory?, w: Cycles of Contingency. Developmental Systems and Evolution, ed. S. Oyama, P. E. Griffiths, R. D. Gray, Cambridge 2001, s. 1-11.

50 Zob. S. Oyama, P. E. Griffiths, R. D. Gray, Introduction..., dz. cyt., s. 1-2.

51 S. Oyama, Evolution's Eye. A Systems View of the Biology-Culture Divide, Durham-London 2000, s. 1. 
tworzą one dynamiczny, samoorganizujący się i samoodtwarzający układ, który zwykliśmy nazywać organizmem. Ciąg następujących po sobie i połaczonych przyczynowo pojedynczych organizmów - cyklów życiowych - tworzy ewoluującą linię filogenetyczna. Podstawa ewolucji jest tu przekazywanie oraz odtwarzanie zasobów rozwojowych pomiędzy cyklami. Ponieważ dziedziczone w ten sposób zasoby należeć mogą do każdego z wymienionych poziomów organizacji biologicznej, tym samym DST operuje niezwykle pojemnym rozumieniem dziedziczności, uwzględniającym zarówno czynniki genetyczne, jak i epigenetyczne, a nawet środowiskowe i kulturowe. W tym momencie zrozumiałe staje się bezkompromisowe sformułowanie głównego celu przyświecającego badaniom nad DST:

(...) teoria ta ma na celu dostarczyć wyjaśnienie międzypokoleniowej stabilności form, które nie odwoływałoby się do genetycznego przekazywania planu czy też programu - owego pseudowyjaśnienia hamującego prace nad autentycznymi mechanizmami rozwoju. [Zamiast tego] skupia się ona na zasobach rozwojowych, które będąc obecne w każdym pokoleniu, odpowiedzialne sa za cechy stabilnie odtwarzane w danej linii rozwojowej52.

Zauważmy, że cecha samoreplikacji, w genocentryzmie przypisywana czassteczce DNA, jest tutaj atrybutem całego cyklu życia organizmu, który odtwarza sam siebie w kolejnych pokoleniach przy wykorzystaniu dziedziczonych zasobów rozwojowych. Współgra to z uwagą Lewontina, że ,jeżeli o czymkolwiek na świecie można powiedzieć, że się samoreplikuje, to nie jest to gen, lecz cały organizm jako układ złożony" ${ }^{3}$.

Z powyższej charakterystyki wynika, że powszechnie używane w biologii ostre rozróżnienia pomiędzy organizmem a środowiskiem, czynnikami genetycznymi i pozagenetycznymi, cecha-

52 P. Griffiths, R. Gray, Developmental Systems and Evolutionary Explanation, „The Journal of Philosophy” 91 (1994) no. 6, s. 286.

${ }_{53}$ Zob. R. Lewontin, Biology as Ideology. The Doctrine of DNA, New York 1993, s. 48 . 
mi wrodzonymi i nabytymi są nietrafne i prowadzą do błędnego rozpoznania mechanizmów rządzących biosferą. Wszystkie one opierają się na założeniu, że da się klarownie odseparować dwa typy przyczyn: genetyczne i środowiskowe, organizm powstaje zaś jako wypadkowa in ter a kcji między nimi. Co najmniej od czasów Francisa Galtona toczy się w nauce zacięty spór dotyczący stopnia i zakresu wpływu, który geny i środowisko mają na rozwijajacy się organizm (tzw. nature vs. nurture debate). Jego temperatura gwałtownie wzrasta, gdy tylko dyskutowanym obiektem staje się człowiek, głos w dyskusji zabierali zaś badacze tej miary co Franz Boas, Ruth Benedict, James Watson, Edward Wilson, Richard Lewontin czy Steven Pinker. Jednakże z punktu widzenia DST cała dyskusja jest bezprzedmiotowa, gdyż problem wyjściowy jest źle postawiony. Ontogenezy nie da się sprowadzić do prostej interakcji między czynnikami genetycznymi i środowiskowymi, w której problemem pozostaje jedynie ustalenie proporcji między obydwoma. DST odrzuca sztywny, dychotomiczny, interakcyjny obraz świata ożywionego, w jego miejsce proponując kontekstowość i współzależność rozmaitych elementów tworzących system rozwojowy ${ }^{54}$. Geny są zaledwie jednym z wielu dostępnych zasobów rozwojowych, obok białek, cytoplazmy komórki jajowej, pożywienia, symbiontów, rozmaitych czynników ekologicznych czy wreszcie - kulturowych. Oczywiście każdy z tych zasobów pełni odmienną rolę w innym miejscu i czasie w ramach rozwoju organizmu, ale nie widać żadnych powodów, dla których mielibyśmy dzielić je wszystkie na dwie odrębne kategorie. Rola genów w tej skomplikowanej sieci zależności nie jest bardziej wyjątkowa niż jakiegokolwiek innego elementu ${ }^{55}$.

Jasnym staje się, że czynniki modelujące dynamiczny rozwój tak rozumianego organizmu nie mogą być sztywno ulokowane w jakiejkolwiek wyizolowanej strukturze fizycznej. Jeżeli nawet chcielibyśmy za taki czynnik uznać informację, to nie sposób wskazać na konkretny obiekt i stwierdzić: „informacja biologiczna znajduje się

54 Zob. P. Łuków, C. Żekanowski, Pojęcie genu..., dz. cyt., s. 103.

55 Zob. P. Griffiths, R. Gray, Developmental Systems..., dz. cyt., s. 277. 
właśnie tutaj" ${ }^{56}$. Informacja rozwojowa zdaje się raczej rozproszona w całym systemie. Co więcej, nie jest ona przekazywana międzypokoleniowo w postaci zakodowanych pakietów, jak tego chca zwolennicy genocentryzmu, lecz każdorazowo odtwarzana (z modyfikacjami) w procesie ontogenezy kolejnego cyklu życia w danej linii filogenetycznej. Informacja nie jest tu stabilna, lecz dynamiczna, nie jest kopiowana, lecz rekonstruowana, nie zostaje ulokowana, lecz wyłania się z interakcji pomiędzy rozmaitymi zasobami rozwojowymi ${ }^{57}$. Tak właśnie należy rozumieć tytuł książki Oyamy - informacja nie tylko nie determinuje ontogenezy; w każdym kolejnym cyklu rozwojowym ona sama jest rekonstruowana i odbudowywana - ma własną ontogenezę.

\section{Krytyka DST}

Perspektywa tak heterodoksyjna, a zarazem krytyczna wobec dominujaccego paradygmatu oraz ambitna, jak DST nie mogła nie zostać skrytykowana. Kim Sterelny, Kelly C. Smith i Michael Di ck s o n zwracają uwagę na fakt, że przy tak szerokim, inkluzywnym rozumieniu systemu rozwojowego nie jesteśmy w stanie nakreślić jego granic, a co za tym idzie - jednoznacznie wskazać, które elementy doń należa, a które już nie. Czy Elvis Presley jest częścia mojego systemu rozwojowego ze względu na rolę, jaka pełni w wykształceniu mojej wrażliwości muzycznej, czy raczej nie? Nie widać wszakże żadnego biologicznie akceptowalnego sposobu dla włączenia Presleya w mój cykl życia ${ }^{58}$. Ci sami autorzy wskazują również, że chociaż systemy rozwojowe odtwarzają się międzypokoleniowo, to jednak trudno jest wskazać granicę między poszczególnymi pokole-

56 S. I. Walker, P. C. W. Davies, The Algorithmic Origins of Life, „Journal of the Royal Society Interface”, http://rsif.royalsocietypublishing.org/content/10/79/20120869 (28.11.2017).

57 Zob. J. S. Roberts, B. K. Hall, W. M. Olson, Bridging the Gap between Developmental Systems Theory and Evolutionary Developmental Biology, „BioEssays” 10 (2001) no. 23, s. 954-962.

${ }_{58}$ Zob. K. Sterelny, K. C. Smith, M. Dickson, The Extended Replicator, dz. cyt., s. 382 . 
niami. Systemu rozwojowego nie można bowiem utożsamiać z klasycznie rozumianym organizmem. W którym momencie rozpoczyna się dany system? Czy powinniśmy liczyć go od ptaka do ptaka? Od jaja do jaja? A może od gniazda do gniazda? ${ }^{59}$

Thom a s Pradeu z kolei zwraca uwagę na niespójność w podejściu do organizmu w ramach DST. Okazuje się, że w teorii tej funkcjonuja de facto dwa różne rozumienia tego terminu: pierwsze odnosi się do jednostkowych procesów rozwojowych, a drugie używane jest do przeformułowania idei ewolucji przy użyciu siatki pojęciowej DST. Pradeu wykazuje, że są to dwie różne definicje, i dochodzi do wniosku, że teoria, która nimi operuje, nie może zostać uznana za zunifikowaną wizję rozwoju i ewolucji, wbrew temu, co deklarują jej zwolennicy ${ }^{60}$.

\section{Krytyka pojęcia informacji biologicznej}

Przedstawione powyżej teorie, pomimo dzielących je różnic, nie negują fundamentalnego sensu posługiwania się pojęciem informacji w biologii. Proponują co najwyżej jego odmienną konceptualizację na gruncie różnych założeń i przesłanek. Poniżej natomiast przedstawię filozoficzne krytyki podważające ogólną trafność i użyteczność posługiwania się tym pojęciem w naukach o życiu.

Sahotra Sarkar, bazując na szczegółowych analizach historii rozwoju biologii molekularnej, identyfikuje powody, dla których przedstawiciele tej subdyscypliny powinni być szczególnie ostrożni w odniesieniu do pojęcia informacji (a nie sa). Następnie stawia tezę, że pojęcie informacji biologicznej ,jest niewiele więcej niż metaforą przebraną w szaty pojęcia teoretycznego i (...) prowadząca do błędnego wyobrażenia co do istoty możliwych wyjaśnień w biologii molekularnej”61. Rozważania swoje wieńczy następującą alternatywą:

${ }^{59}$ Zob. K. Sterelny, K. C. Smith, M. Dickson, The Extended Replicator, dz. cyt., s. 383 .

60 Zob. T. Pradeu, The Organism in Developmental Systems Theory, „Biological Theory" 5 (2010) iss. 3, s. 216-222.

61 S. Sarkar, Biological Information: A Sceptical Look at some Central Dogmas of Molecular Biology, w: The Philosophy and History of Molecular Biology: New Per- 
albo pojęcie informacji w odniesieniu do układów badanych przez biologię molekularna zostanie odpowiednio wyeksplikowane, albo dyscyplina ta powinna całkowicie odrzucić posługiwanie się terminologia informacyjna (information talk) na rzecz konsekwentnego fizykalizmu terminologicznego. I dorzuca pesymistyczną konkluzję, że aczkolwiek oba rozwiązania są możliwe, to jednak drugie z nich wydaje się bardziej prawdopodobne.

Przyjmując krytykę Sarkara za punkt wyjścia, B a rt on M off at stwierdza, że chcąc odpowiedzieć na pytanie o sens pojęcia informacji w biologii, powinniśmy przyjrzeć się praktyce biologów. Tymczasem toczone (głównie przez filozofów) dyskusje mówią więcej o kondycji współczesnej filozofii niż o biologii. Filozofowie powinni wiedzieć, co dokładnie robią biolodzy, gdy używają terminu „informacja”, nim zaczna ganić bądź chwalić ich za używanie tego pojęcia. Błąd popełniany przez filozofów polega na tym, że zaczynaja oni od rozwinięcia pewnej teorii informacji, w której pojęcie to jest szczegółowo zdefiniowane, po czym stosująją do biologii, dochodząc zazwyczaj do wniosku, że praktyka użycia tego pojęcia przeczy ich oczekiwaniom, co świadczyć ma jakoby o pomieszaniu konceptualnym w biologii. W miejsce dyskusji nad informacja proponuje on zatem dyskusję nad pojęciem „sygnału”, które jego zdaniem jest powszechnie stosowane w biologii, tymczasem nie doczekało się jeszcze rzetelnej filozoficznej analizy. Moffat proponuje rozumienie tego terminu przez pryzmat pojęcia funkcji. Być sygnałem to pełnić określona funkcję w układzie biologicznym. Posługując się przykładami z zakresu biologii komórki i mikrobiologii, pokazuje on, że pojęcie sygnału wystarcza do wyjaśnienia procesów zachodzących w komórkach bakteryjnych bądź między nimi, bez konieczności odwoływania się do pojęcia informacji z całym jego obciążeniem filozoficznym, respektując jednocześnie badawczą praktykę biologiczna ${ }^{62}$.

spectives, ed. S. Sarkar, Dordrecht 1996, s. 187.

${ }^{62}$ Zob. B. Moffat, A Reexamination of Biological Information from the Perspective of Practice, http://philsci-archive.pitt.edu/4803 (22.11.2017). 


\section{Podsumowanie}

Syntezę opisanych różnic między genocentrycznym a rozwojowym rozumieniem bioinformacji zawiera poniższa tabelka.

\begin{tabular}{|c|c|}
\hline Ujęcie genocentryczne & Teoria systemów rozwojowych \\
\hline $\begin{array}{l}\text { Informacja rozwojowa jest tożsama } \\
\text { z genetyczną informacją molekular- } \\
\text { ną zapisaną w łańcuchu DNA (re- } \\
\text { dukcjonizm). }\end{array}$ & $\begin{array}{l}\text { Informacja rozwojowa nie jest reduko- } \\
\text { walna do informacji genetycznej (nie } \\
\text { jest ulokowana, lecz rozproszona oraz } \\
\text { kontekstowa - pluralizm). }\end{array}$ \\
\hline $\begin{array}{l}\text { Jej istnienie wyprzedza i determi- } \\
\text { nuje rozwój osobniczy (preformacjo- } \\
\text { nizm). }\end{array}$ & $\begin{array}{l}\text { Jest ona każdorazowo konstruowana } \\
\text { w procesie ontogenezy, a nie - przeka- } \\
\text { zywana w procesie replikacji DNA lub } \\
\text { „tłumaczona” na białka. }\end{array}$ \\
\hline $\begin{array}{l}\text { Pozagenetyczne elementy organi- } \\
\text { zmu nie pełnią funkcji informacyj- } \\
\text { nej, lecz wyłącznie pomocniczą lub } \\
\text { budulcowa. }\end{array}$ & $\begin{array}{l}\text { Wyraźny podział na obiekty będące } \\
\text { nośnikami informacji oraz takie, któ- } \\
\text { re umożliwiają jej odczyt i ekspresję } \\
\text { (same nie będąc nośnikami), nie jest } \\
\text { możliwy. }\end{array}$ \\
\hline $\begin{array}{l}\text { Zakłada się możliwość klarowne- } \\
\text { go wyodrębnienia organizmu ze śro- } \\
\text { dowiska (istnieje wyraźna granica } \\
\text { między organizmem a jego otocze- } \\
\text { niem). }\end{array}$ & $\begin{array}{l}\text { Nie jest możliwe dokonanie wyraźne- } \\
\text { go rozdziału na organizm i środowisko; } \\
\text { zamiast tego postuluje się myślenie } \\
\text { w kategoriach cykli życia (life cycles). }\end{array}$ \\
\hline $\begin{array}{l}\text { Środowisko traktowane jest jako } \\
\text { źródło presji selekcyjnej kształtuja- } \\
\text { cej pulę genetyczna populacji w cza- } \\
\text { sie i napędzającej w ten sposób } \\
\text { proces ewolucji w drodze doboru na- } \\
\text { turalnego. }\end{array}$ & $\begin{array}{l}\text { Proces ewolucji nie dotyczy wyłącz- } \\
\text { nie molekularnej informacji genetycz- } \\
\text { nej zapisanej w DNA, lecz całych sys- } \\
\text { temów rozwojowych. }\end{array}$ \\
\hline
\end{tabular}

Sądzę, że istotę zmiany proponowanej w ramach teorii systemów rozwojowych trafnie można opisać jako propozycję porzucenia genocentrycznej wizji świata ożywionego, w której jednoznacznie zidentyfikowano przyczyny rozwoju organizmów (intencjonalnie rozumiana informacja ulokowana w molekularnie rozumianych genach) na rzecz dynamicznego ujęcia interakcyjnego, w którym informacja jest własnością systemową i rozproszona, geny są zaś koniecz- 
nym, ale bynajmniej nie wystarczającym warunkiem funkcjonowania organizmów ${ }^{63}$.

DST bywa krytykowana za niemożność zaproponowania spójnej strategii doświadczalnej dla badania układów o tak dużym stopniu wewnętrznej złożoności, jak systemy rozwojowe. Być może jednak najważniejszą lekcja płynącą z lektury teoretyków DST jest pytanie o obiektywne istnienie (bądź nieistnienie) poziomów organizacji biologicznej, stanowiacych punkty odniesienia w praktyce badawczej nad procesami rozwojowymi oraz procesami ewolucji ${ }^{64}$.

\section{Summary}

\section{Genocentrism versus developmental systems theory. Two competing ways of understanding information in modern biology}

There are (at least) two opposing concepts of biological information, or bioinformation, discussed in the modern philosophy of biology: genocentric (genebased) and holistic. As a main proponent of the former I consider British evolutionist John Maynard Smith and his teleosemantic theory of bioinformation. The latter was proposed by American philosopher Susan Oyama in the form of so-called Developmental Systems Theory (DST).

In Maynard Smith proposal bioinformation is strictly gene-based and any non-genetic element of a living organism cannot be considered as a vehicle of informational content. Such information is transmitted from parents to offspring inside the germ cells and every time serves as a blueprint for building the whole organisms. DST claims the opposite: bioinformation cannot be reduced to genetic elements only and is scattered throughout the whole living system. What is more, biological information is not simply transmitted between generations but every time rebuilt from available developmental resources: bioinformation has not only it is phylogeny, but it is ontogeny as well. The aim of this paper is twofold. First: to present the foundations of both aforementioned theories to the reader and second: to discuss the different objections raised against them.

Keywords: genocentrism, Developmental Systems Theory, biological information, bioinformation, John Maynard Smith, Susan Oyama

63 Zob. F. Nijhout, Metaphors and the Role..., dz. cyt., s. 444.

${ }_{64}$ Zob. P. Łuków, C. Żekanowski, Pojęcie genu..., dz. cyt., s. 103. 


\section{Bibliografia}

Cobb M., Największa tajemnica ̇̇ycia. Jak rozszyfrowano kod genetyczny, tłum. A. Tuz, Warszawa 2017.

Downes S. M., Biological Information, w: The Philosophy of Science: An Encyclopedia, ed. S. Sarkar, J. Pfeifer, New York 2004.

Frank S. A., Host Control of Symbiont Transmission: The Separation of Symbionts into Germ and Soma, „The American Naturalist” 148 (1996) no. 6, s. 1113-1124.

Freeland S., Hurst L., Ewolucja języka genów, „Świat Nauki” (2004) nr 5, s. $56-63$.

Gaczoł R., Spór Richarda Dawkinsa ze Stephenem Jayem Gouldem wokół teorii samolubnego genu, „Przegląd Filozoficzno-Literacki” 31 (2011) nr 2-3, s. $87-106$.

Gilbert W., A Vision of the Grail, w: The Code of Codes. Scientific and Social Issues in the Human Genome Project, ed. D. J. Kevles, L. Hood, Cambridge 1992.

Godfrey-Smith P., Information in Biology, w: The Cambridge Companion to the Philosophy of Biology, ed. D. L. Hull, M. Ruse, Cambridge 2007.

Godfrey-Smith P., Information, Arbitrariness, and Selection: Comments on Maynard Smith, „Philosophy of Science” 67 (2000) no. 2, s. 202-207.

Godfrey-Smith P., On the Theoretical Role of “Genetic Coding”, „Philosophy of Science" 67 (2000), s. 26-44.

Godfrey-Smith P., Sterelny K., Biological Information, w: The Stanford Encyclopedia of Philosophy, ed. E. N. Zalta, https://plato.stanford.edu/entries/information-biological (22.11.2017).

Griffiths P., Genetic Information: A Metaphor in Search of a Theory, „Philosophy of Science" 68 (2001), s. 394-412.

Griffiths P., Gray R., Developmental Systems and Evolutionary Explanation, „The Journal of Philosophy” 91 (1994) no. 6, s. 277-304.

Griffiths P., Knight R., What Is the Developmentalist Challenge?, „Philosophy of Science" 65 (1998) no. 2, s. 253-258.

Jablonka E., Information: Its Interpretation, Its Inheritance, and Its Sharing, „Philosophy of Science” 69 (2002) no. 4, s. 578-605. 
Jacob F., Monod J., Genetic Regulatory Mechanisms in the Synthesis of Proteins, „Journal of Molecular Biology” 3 (1961) iss. 3, s. 318-356.

Keller E. F., The Century of the Gene, Cambridge 2000.

Küppers B. O., Geneza informacji biologicznej. Filozoficzne problemy powstania $\dot{z} y c i a$, tłum. W. Ługowski, Warszawa 1991.

Lewontin R., Biology as Ideology. The Doctrine of DNA, New York 1993.

Lewontin R., Gene, Organism and Environment, w: Evolution from Molecules to Men, ed. D. S. Bendall, Cambridge 1983.

Lewontin R., It ain't Necessarily so. The Dream of the Human Genome and Other Illusions, New York 2001.

Lewontin R., Organism and Environment, w: Learning, Development, and Culture, ed. H. C. Plotkin, New York 1982.

Łuków P., Żekanowski C., Pojęcie genu i genocentryczny paradygmat biologii, „Przegląd Filozoficzny” 14 (2005) nr 53, s. 85-105.

Maynard Smith J., The Concept of Information in Biology, „Philosophy of Science" 67 (2000) no. 2, s. 177-194.

Moffat B., A Reexamination of Biological Information from the Perspective of Practice, http://philsci-archive.pitt.edu/4803 (22.11.2017).

Nijhout F., Metaphors and the Role of Genes in Development, „BioEssays” 12 (1990) iss. 9, s. 441-446.

Noble D., The Music of Life. Biology Beyond Genes, Oxford 2006.

Oyama S., Evolution's Eye. A Systems View of the Biology-Culture Divide, Durham-London 2000.

Oyama S., Griffiths P. E., Gray R. D., Introduction. What Is Developmental Systems Theory?, w: Cycles of Contingency. Developmental Systems and Evolution, ed. S. Oyama, P. E. Griffiths, R. D. Gray, Cambridge 2001.

Oyama S., The Ontogeny of Information, Cambridge 1985.

Pinto-Correia C., The Ovary of Eve. Egg and Sperm and Preformation, Chicago 1997.

Pradeu T., The Organism in Developmental Systems Theory, „Biological Theory" 5 (2010) iss. 3, s. 216-222.

Roberts J. S., Hall B. K., Olson W. M., Bridging the Gap between Developmental Systems Theory and Evolutionary Developmental Biology, „BioEssays” 10 (2001) no. 23, s. 954-962. 
Sarkar S., Biological Information: A Sceptical Look at some Central Dogmas of Molecular Biology, w: The Philosophy and History of Molecular Biology: New Perspectives, ed. S. Sarkar, Dordrecht 1996.

Sterelny K., Smith K. C., Dickson M., The Extended Replicator, „Biology and Philosophy” 11 (1996), s. 377-403.

Sterelny K., Symbiosis, Evolvability and Modularity, w: Modularity in Development and Evolution, ed. G. Schlösser, G. P. Wagner, Chicago 2004.

Sterelny K., The “Genetic Program” Program: A Commentary on Maynard Smith on Information in Biology, „Philosophy of Science” 67 (2000) no. 2, s. 195-201.

Szathmáry E., Maynard Smith J., The Major Evolutionary Transitions, „Nature" 374 (1995), s. 227-232.

Walker S. I., Davies P. C. W., The Algorithmic Origins of Life, „Journal of the Royal Society Interface", http://rsif.royalsocietypublishing.org/content/10/79/20120869 (28.11.2017).

Waters K., Molecular Genetics, w: The Stanford Encyclopedia of Philosophy, ed. E. N. Zalta, https://plato.stanford.edu/entries/molecular-genetics (22.11.2017).

Weber M., Philosophy of Experimental Biology, Cambridge 2005.

Wright L., Functions, „The Philosophical Review” 82 (1973) no. 2, s. 139-168. 